TRABAJOS DE PREHISTORIA

71, N. ${ }^{\circ}$ 2, julio-diciembre 2014, pp. 343-352, ISSN: 0082-5638

doi: $10.3989 /$ tp. 2014.12138

\title{
Dating of Las Mesas Copper Age walled enclosure (La Fuente, Spain)
}

\author{
Datación del recinto murado calcolítico de Las Mesas (La Fuente, España)
}

\author{
Carlos P. Odriozola (*) \\ Christopher I. Burbidge (**) \\ M. Isabel Dias (**) \\ Víctor Hurtado (*)
}

\begin{abstract}
The site of Las Mesas is located in the west bank of the Guadajira river (La Fuente, Badajoz, Spain). It covers a half hectare and is enclosed by a stone wall. Previous assessments based on site surveys suggested a general chronological span from Late Neolithic period (ca. 36002900 BC) through the Copper Age ( $3^{\text {rd }}$ millennium BC). Excavations revealed a well-constructed wall with bastions and a domestic space at the centre of the site with three occupational phases. Several functional areas and a votive pit are ascribed to the second phase.

A deer antler located in a re-cut ritual pit associated to the second phase was dated by $\mathrm{AMS}-{ }^{14} \mathrm{C}$. Samples from a living floor assigned to the second phase (SU9/10) and the basement of a kiln associated with the first phase (SU-18) was dated by optically stimulated luminescence (OSL) using the single aliquot regenerative dose (SAR) protocol on $90-160 \mu \mathrm{m}$ quartz grains. Luminescence profiling analysis of 7 samples taken throughout the archaeological stratigraphy was used to assess variations in luminescence behaviour and relative age through the sequence, using infrared-, optically -and thermallystimulated luminescence (IRSL, OSL, TSL) on poly-mineral and etched samples.

Luminescence dating and profiling indicates that the upper archaeological layer (SU-1B) probably dates to the Late Bronze Age ( $c a .1000 \mathrm{BC}$ ), but that the sediments in the remainder of this section accumulated during the late Neolithic-Copper Age: the site was most probably inhabited between 3300 and 2900 BC. There were gaps in occupation between the Late Neolithic-Cooper Age
\end{abstract}

(*) Department of Prehistory and Archaeology. University of Sevilla. C/ Doña María de Padilla s/n. 41004 Sevilla. Spain. E-mail: Carlos.odriozola@gmail.com; vhurtado@us.es

(**) Campus Tecnológico e Nuclear. Instituto Superior Técnico. Universidade Técnica de Lisboa. Estrada Nacional 10. 2695-066 Bobadela LRS-Portugal.

E-mail: isadias@ctn.ist.utl.pt; christoph@ctn.ist.utl.pt

Received: 9-IV-2013; accepted: 20-VI-2013. phases (I \& II), and between the Late Neolithic-Cooper Age phases and Late Bronze Age phase (II \& III), indicating that the site was abandoned and reoccupied twice. The AMS- ${ }^{14} \mathrm{C}$ date on deer antler of $4254 \pm 45$ BP (3010$2675 \mathrm{cal} \mathrm{BC}$ ) is consisten with the OSL results for phase II, indicating that the pit was excavated at the beginning of the second occupational phase.

Combined OSL and AMS-14C dating shows that Las Mesas site was first occupied during Late Neolithic farming colonization, abandoned during the Copper Age and occupied again during the Late Bronze Age. The occupational gap recorded during the Copper Age relates to evidence for burning of the site and the partial destruction of the wall, followed by its reconstruction and consolidation.

\section{RESUMEN}

El yacimiento amurallado de media hectárea de Las Mesas se ubica en la margen oeste del río Guadiana (La Fuente, Badajoz, España). El análisis de la cultura material recuperada en prospecciones de superficie remite a un arco cronológico que va desde el Neolítico Final (ca. 3600-2900 AC) a la Edad del Cobre (III milenio AC). Las excavaciones han revelado una muralla polibastionada y un espacio habitacional en el centro del asentamiento con tres fases de uso, diferentes áreas funcionales y un hoyo votivo adscrito a la segunda fase.

En un hoyo ritual efectuado en la segunda fase se ha recuperado una cornamenta de cérvido que ha sido datado mediante AMS-14C. Se analizaron por Luminiscencia Ópticamente Estimulada (OSL) muestras de un nivel de uso de suelo asignado a la segunda fase (UE-9/10) y de la base de un horno asociado a la primera fase (UE18). Se aplicó un procedimiento de Dosis Única Regenerativa (SAR) sobre la fracción de granos de cuarzo de 90-160 $\mu \mathrm{m}$. Se efectuó también un análisis de 7 muestras tomadas de la estratigrafía para determinar las variaciones de la conducta luminiscente y la edad relativa a través de la secuencia estratigráfica en muestras polimi- 
nerales mediante luminiscencia estimulada infrarojaópticamente y térmicamente (IRS1, OSL, TSL).

La datación y el perfil luminiscente indican que el nivel superior $(U E-1 B)$ pertenecería probablemente al Bronce Final (ca. 1000 AC), pero que el resto de la secuencia estratigráfica se corresponde con una ocupación del Neolítico Final-Edad del Cobre. Siendo lo más probable que la ocupación del sitio tuviera lugar entre el 3300 y el 2900 AC. Se detectan vacios de ocupación entre la fase I y II, y entre la fase II y la ocupación del Bronce Final (fase III). Indicando que el asentamiento fue abandonado y reocupado en dos ocasiones, una en la Edad del Cobre y una en el Bronce Final. La fecha de $4254 \pm 45$ BP (3010-2675 cal AC) obtenida mediante AMS-14C coincide con las fechas luminiscente de la fase II, apuntando que el hoyo fue excavado al principio de la fase II.

Las fechas luminiscentes y radiocarbónicas combinadas muestran que el asentamiento de Las Mesas fue ocupado durante la colonización agrícola del territorio que tuvo lugar en el Neolítico Final, abandonado durante la Edad del Cobre y reocupado en el Bronce Final. Los vacios poblacionales registrados podrían relacionarse con las evidencias de quemado y destrucción parcial de la muralla del asentamiento, y su posterior reconstrucción y consolidación.

Key words: Luminescence dating; Radiocarbon dating, enclosure; Late Neolithic; Copper Age; Extremadura; Badajoz; Spain.

Palabras clave: Datación luminiscente; Datación radiocarbónica; Recinto murado; Neolítico Final; Edad del Cobre; Extremadura; Badajoz; España.

\section{INTRODUCTION}

In the Counties of Tierra de Barros and Mérida (Badajoz, Spain), most of the ca. 150 Late Prehistoric sites are only known from archaeological survey (Hurtado 2008). Exploratory excavations have been conducted at fifteen of these sites; only three have been subject to absolute dating (Tab. 1). The techno-cultural ascription of the remaining sites was based on ceramic typology: the presence, absence or mixing proportion of thickened rim plates and carinated bowls (Enríquez Navascués 1989; Hurtado and Mondejar 2008). Following this approach, $90 \%$ of the located sites were ascribed to Middle and Late Copper Age, and the remainder to the Late Neolithic or Early Copper Age.

The development of Las Mesas site is situated within the processes of cultural evolution and social dynamics proposed for Tierra de Barros (Hurtado 1995); namely colonization by Late Ne-
olithic-Early Copper Age settlers and the formation of a pre-state hierarchized landscape (Hurtado 1995, 1999; Garcia Sanjuán 1997). Recent research points to a pacific colonization of Tierra de Barros and Mérida lands in the "Araya phase" (3300-2900 cal BC), around the transition from the Late Neolithic to Early Copper Age. Settlers may have come from either the Tagus River Middle Basin, or from the neighbouring region of Reguengos de Monsaraz (Hurtado 1995, 1999). The subsequent "La Pijotilla phase" (2900-2600 cal BC) represents an exponential population growth and population spread through the landscape with an associated increase in violence and the fortification of sites in strategic points (Hurtado 1995). Most surveyed sites $-90 \%$ - have been ascribed to "La Pijotilla phase", which correlates with the Middle Copper Age. However, this ascription was based on the assumption that the preponderance of thickened rim plates indicates a Middle-Late Copper Age date, despite the observation of this pottery type in Late Neolithic-Early Copper Age contexts. At Las Mesas, existing techno-cultural assessments, based on ceramics with thickened rim plates and architectural features of the walls, suggested a general chronological span from Middle (ca. 2900-2600 cal BC) through Late Copper Age (ca. 2600-1800 cal BC).

Surveys and pottery seriating is a practical approach for rapid and generalized understanding of developments in the archaeological landscape and the political, economic and social units within it, and the construction of hypotheses for sequences of cultural evolution. However, this methodology lacks of precision and accuracy because it relies on the evolution of style and decorative patterns, which are subject to geographical and cultural differences and, in general, spread in time. Site specific absolute dating provides a chronological framework with better precision than that available from conventional examination of the material remains from a site or survey.

Where suitable organic material is available, AMS-14C dating offers the best precision; subject to fluctuations in its calibration curve in later Prehistory. Luminescence dating may be applied to material culture (ceramics), and may also be applied to directly date the last exposure to light of the sediments accumulated in a given archaeological context.

The archaeological sequence of Las Mesas in Tierra de Barros County (Badajoz, Spain), pro-

Trab. prehist., 71, N. ${ }^{\circ}$ 2, julio-diciembre 2014, pp. 343-352, ISSN: 0082-5638

doi: $10.3989 /$ tp.2014.12138 
$1 \mathrm{~A}$

\begin{tabular}{|c|c|c|c|c|c|c|}
\hline Site & Lab. Code & Type & $\begin{array}{c}\text { Conventional }{ }^{14} \mathrm{C} \\
\text { Age years BP }\end{array}$ & Date Cal. BCE & $\delta^{13} \mathrm{C} \%$ & Published \\
\hline La Pijotilla & Beta-121146 & n.p. & $4130+40$ & $\begin{array}{l}2861-2828(0,20) \\
2824-2807(0,09) \\
2757-2718(0,23) \\
\mathbf{2 7 0 6 - 2 6 2 5}(\mathbf{0 , 4 8 )}\end{array}$ & n.p. & Hurtado 1991b \\
\hline La Pijotilla & Beta-121147 & n.p. & $4360 \pm 50$ & $\begin{array}{l}3077-3075(0,01) \\
\mathbf{3 0 2 3 - 2 9 0 9}(\mathbf{0 , 9 9 )}\end{array}$ & n.p. & Hurtado 1991b \\
\hline La Pijotilla & Beta-121146 & n.p. & $4110 \pm 40$ & $\begin{array}{l}2865-2832(0,20) \\
2820-2805(0,08) \\
\mathbf{2 7 6 0 - 2 6 5 8}(\mathbf{0 , 6 1 )} \\
2653-2633(0,11)\end{array}$ & n.p. & Hurtado 1991b \\
\hline La Pijotilla & Beta-121145 & n.p. & $4010 \pm 80$ & $\begin{array}{l}2836-2816(0,06) \\
\mathbf{2 6 7 0 - 2 4 5 7}(\mathbf{0 , 9 1 )} \\
2418-2408(0,02) \\
2375-2367(0,01)\end{array}$ & n.p. & Hurtado 1991b \\
\hline La Pijotilla (tholoi 1) & BM-1603 & n.p. & $3860 \pm 70$ & $\begin{array}{l}\mathbf{2 4 5 9 - 2 2 8 0}(\mathbf{0 , 8 8}) \\
2250-2230(0,09) \\
2219-2212(0,03)\end{array}$ & n.p. & Hurtado 1981 \\
\hline La Pijotilla (tholoi 3) & Beta-121143 & n.p. & $4130 \pm 40$ & $\begin{array}{l}2861-2828(0,20) \\
2824-2807(0,09) \\
2757-2718(0,23) \\
\mathbf{2 7 0 6 - 2 6 2 5}(\mathbf{0 , 4 8})\end{array}$ & n.p. & Hurtado et al. 2000 \\
\hline La Pijotilla (tholoi 3) & CNA-34 & charcoal & $4168 \pm 55$ & $\begin{array}{l}2877-2839(0,21) \\
\mathbf{2 8 1 4 - 2 6 7 6}(\mathbf{0 , 7 9 )}\end{array}$ & $-23.8 \pm 0.2$ & Odriozola et al. 2008 \\
\hline Palacio Quemado & HAR- 8250 & n.p. & $3570 \pm 100$ & 2034-1767 $(0,99)$ & n.p. & $\begin{array}{l}\text { Hurtado and Enríquez } \\
\text { Navascués } 1991\end{array}$ \\
\hline Palacio Quemado & HAR-8249 & n.p. & $4140 \pm 80$ & $\begin{array}{l}2872-2828(0,19) \\
2824-2801(0,10) \\
2792-2786(0,03) \\
\mathbf{2 7 8 0 - 2 6 2 5}(\mathbf{0 , 6 8})\end{array}$ & n.p. & $\begin{array}{l}\text { Hurtado and Enríquez } \\
\text { Navascués } 1991\end{array}$ \\
\hline San Blas & Beta-178651 & charcoal & $3950 \pm 40$ & $\begin{array}{l}2563-2534(0,22) \\
\mathbf{2 4 9 4 - 2 4 4 7}(\mathbf{0 , 4 4}) \\
2446-2437(0,05) \\
2420-2404(0,11) \\
2378-2350(0,18)\end{array}$ & -26.0 & Hurtado 2004 \\
\hline San Blas & Beta-178650 & charcoal & $4030 \pm 40$ & $2580-2481(0,99)$ & -25.1 & Hurtado 2004 \\
\hline San Blas & Beta-178652 & charcoal & $3820 \pm 40$ & $\begin{array}{l}2340-2314(0,13) \\
\mathbf{2 3 1 0 - 2 2 0 0}(\mathbf{0 , 8 5}) \\
2157-2155(0,01)\end{array}$ & -26.1 & Hurtado 2004 \\
\hline San Blas & Beta-178653 & charcoal & $4340 \pm 40$ & $\begin{array}{l}3011-2977(0,37) \\
2966-2948(0,16) \\
\mathbf{2 9 4 4 - 2 9 0 4}(\mathbf{0 , 4 7 )} \\
\end{array}$ & -25.9 & Hurtado 2004 \\
\hline San Blas & Beta-178655 & charcoal & $4570 \pm 40$ & $\begin{array}{l}3487-3473(0,08) \\
\mathbf{3 3 7 2 - 3 3 3 0}(\mathbf{0 , 4 5 )} \\
3215-3182(0,24) \\
3157-3124(0,22) \\
\end{array}$ & -25.9 & Hurtado 2004 \\
\hline San Blas & Beta-169546 & charcoal & $4420 \pm 40$ & $\begin{array}{l}3263-3248(0,07) \\
\mathbf{3 1 0 0 - 3 0 0 7}(\mathbf{0 , 6 5}) \\
2988-2931(0,28) \\
\end{array}$ & -25.9 & Hurtado 2004 \\
\hline San Blas & Beta-178654 & charcoal & $3990 \pm 40$ & $\begin{array}{l}\mathbf{2 5 6 8 - 2 5 1 8}(\mathbf{0 , 6 3 )} \\
2499-2471(0,37) \\
\end{array}$ & -25.6 & Hurtado 2004 \\
\hline
\end{tabular}

n.p.: data not published.

1 B

\begin{tabular}{|c|c|c|c|c|}
\hline Site & Lab. Code & Type & Date BCE & Published \\
\hline La Pijotilla & ITN_LUM_218 & Pottery & $2665 \pm 107$ & Odriozola et al. 2008 \\
\hline La Pijotilla & ITN_LUM_217 & Pottery & $2396 \pm 154$ & Odriozola et al. 2008 \\
\hline La Pijotilla & ITN_LUM_262 & Pottery & $2601 \pm 100$ & Odriozola et al. 2008 \\
\hline La Pijotilla & ITN_LUM_265 & Pottery & $2716 \pm 96$ & Odriozola et al. 2008 \\
\hline
\end{tabular}

*values from (Aitken 1985).

Tab. 1. Dated sites in Tierra de Barros County (1A) 14C dates; (1B) TSL dates. 
vides an unusual opportunity to scientifically analyse three stratigraphic events. Optically stimulated luminescence (OSL) dating and profiling combined with AMS-14C dating have been used to provide significant new chronological data for Tierra de Barros County and to evaluate the applicability of OSL dating in this type of site.

\section{THE SITE, AND IT'S STRATIGRAPHY}

Las Mesas site is located $3.5 \mathrm{~km}$ South Villalba de los Barros vicinity (Badajoz, Spain), over a small flat-topped hill with steep sides of $334 \mathrm{~m}$ in altitude called La Mesa -sheet 829-I 1:25000 IGN maps- at the Guadajira river West riverside bank (Fig. 1) (Hurtado 2008). Based on material culture -pottery, polished axe and hand mills (Hurtado 1991)- the site is ascribed generically to the Copper Age period.
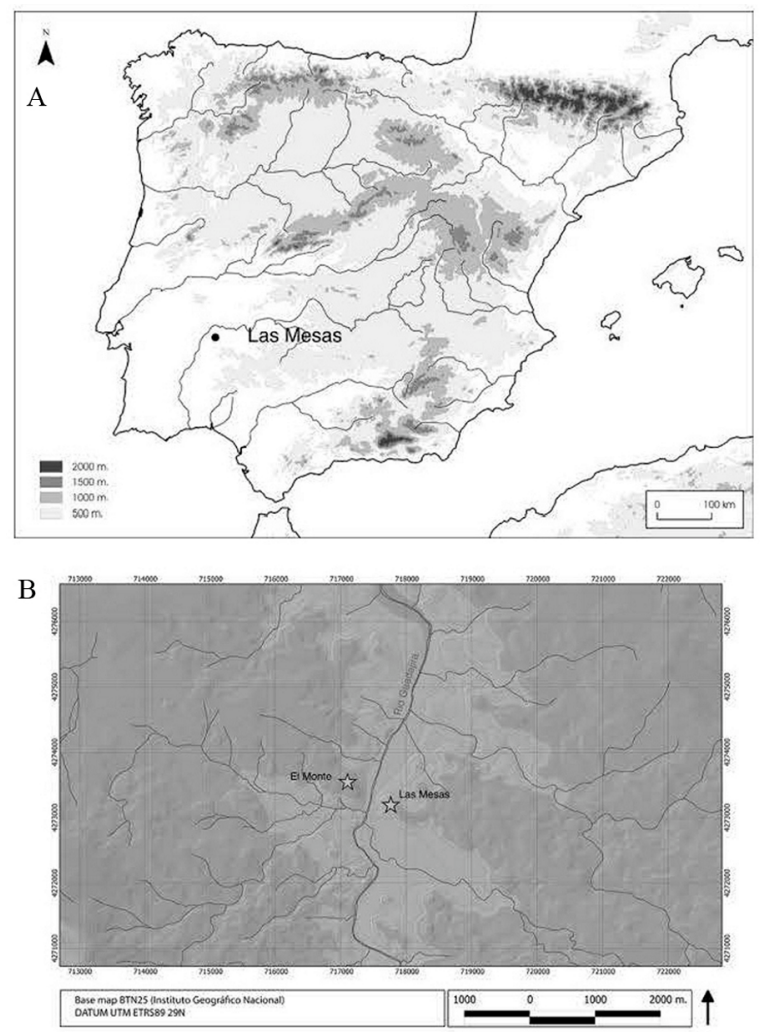

Fig. 1. A) Las Mesas location map in Iberia; B) detailed location of Las Mesas and surrounding sites in the Countries of Tierra de Barros (Badajoz).
The site has been recently excavated in an archaeological rescue action due to the construction of a dam in 2008 (Hurtado 2008). The poly-bastioned stonewalled enclosure of Las Mesas has an extent of $4590 \mathrm{~m}^{2}$, with a pseudo-square shape (Fig. 2A). Excavations were focused on the wall -visible in the landscape as a step- and in the central area of the site. Dam construction mainly determined excavation strategy, such that open area excavation was undertaken only in those areas strictly affected by dam works (wall). Nevertheless, we were allowed to perform some small cuts in the centre of the site and in the perimeter (Fig. 2B).

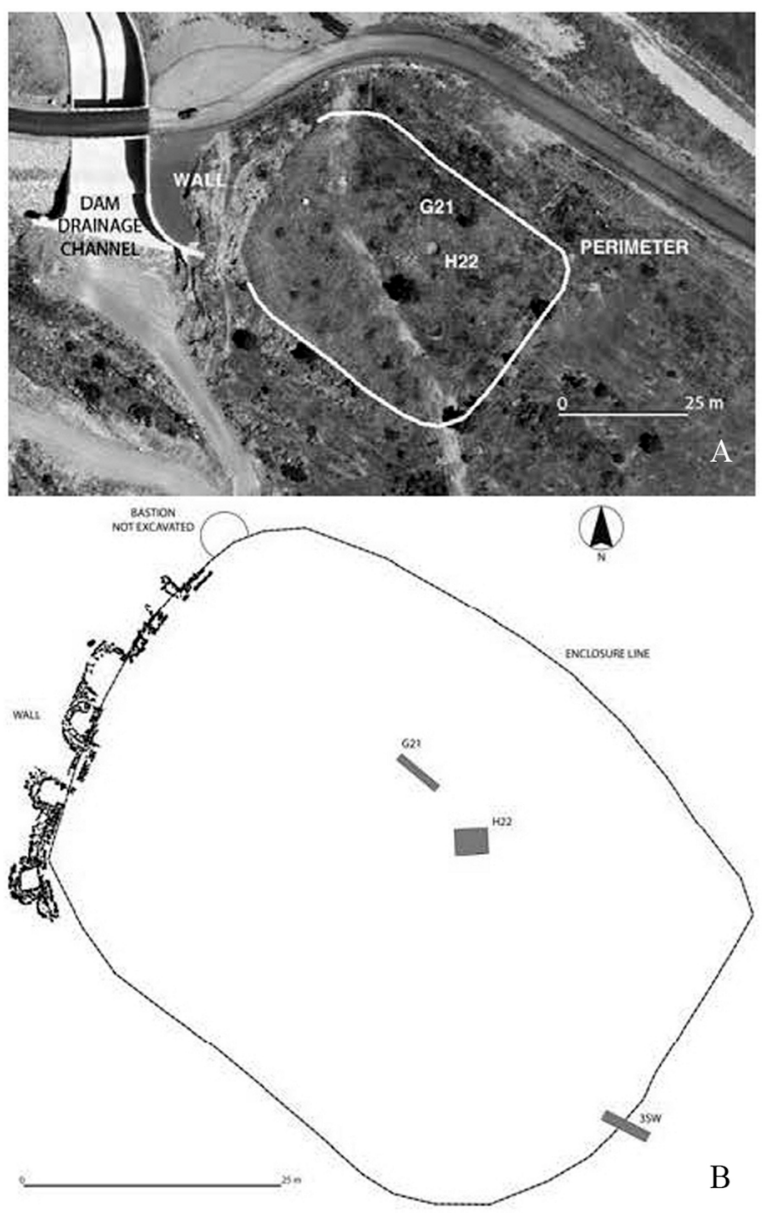

Fig. 2. Satellite photograph of Las Mesas after archaeological works.

The site was excavated following an orthogonal N-S grid labelled alphanumerically. The central excavated area (square H22) contained sev- 


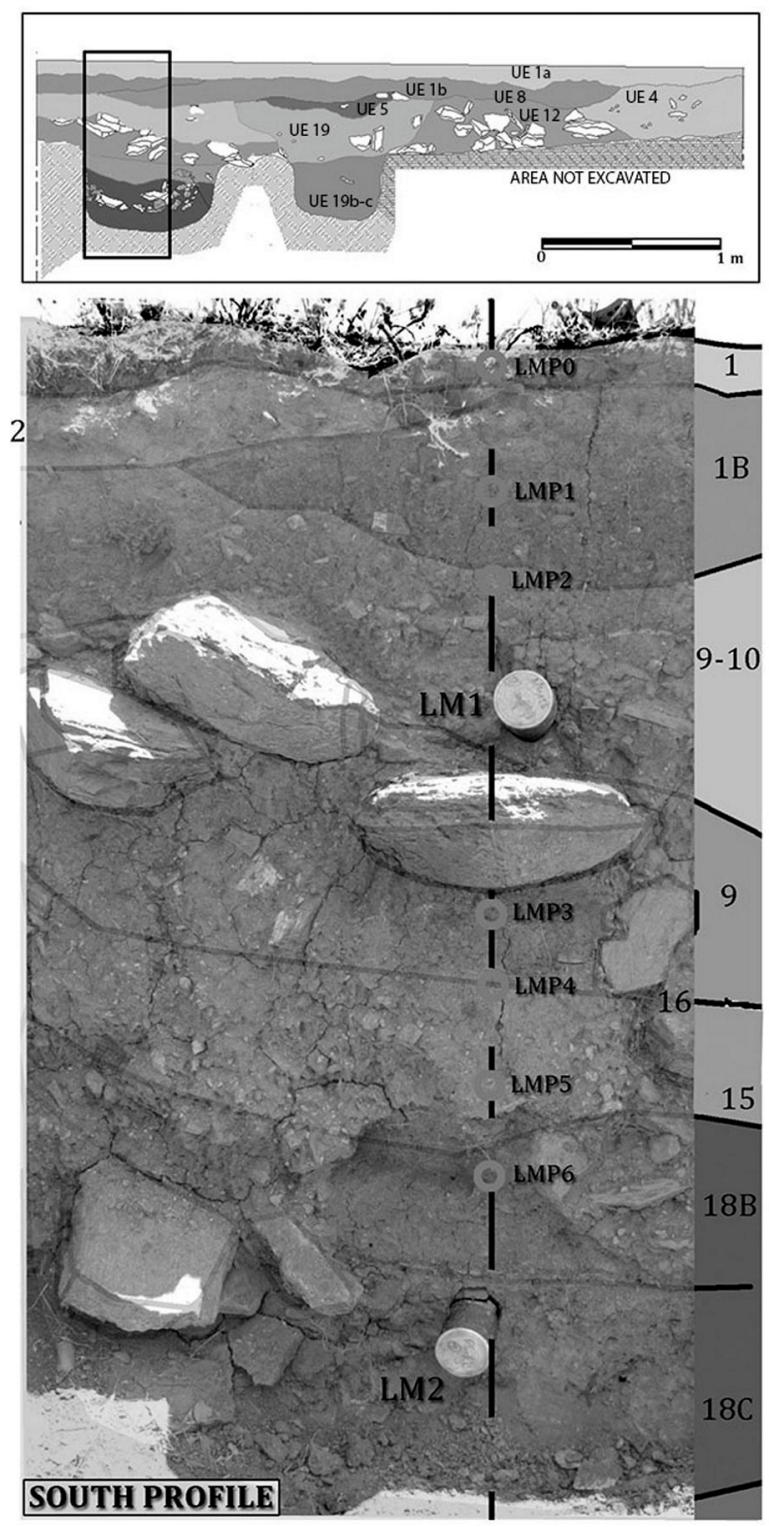

Fig. 3. Diagram showing archaeological works in Las Mesas.

eral functional features excavated in the bedrock and 19 stratigraphic units (SU onwards) assigned to 3 different phases in the stratigraphy (Fig. 3). These included several negative units cutting three layers interpreted as occupation floors: SU 16 (Phase I), SU 12, 13 \& 9/10 (Phase II). Material culture in each phase was similar, indicating occupational continuity. The different phases were initially interpreted as relating to refurbishment of the settlement in the context of continuous occupation.
Phase I is characterized by an occupation floor (SU 16) and the presence of an open firing structure (pit-bonfire) of $0.5 \mathrm{~m}$ deep and $0.8 \mathrm{~m}$ width (SU 18). The open firing structure was carved in the bedrock and covered by a thick layer of clay, over which the fire was set, with no remaining evidence of insulation. The hardness and red colour of the clay layer indicated its conversion to adobe by the action of repeated firing. The functionality of this structure remains unresolved, due essentially to the lack of evidence for use as cooking structure, bonfire, or any other kind of technical functions such as pottery firing. No other structure was found in this area and the space is functionally interpreted as a domestic space, possibly making up part of a hut constructed from perishable materials.

Phase II is characterized by three living floors (SU 12, 13 and 9/10), a pit of $0.64 \mathrm{~m}$ depth and $1.2 \mathrm{~m}$ width (SU 19) of unknown functionality, associated to SU 9/10 and a stone circle (SU 7) that may have act as wedges to support a perishable hut.

The pit is thought to act as a votive re-foundational pit related to the last occupation of the site before its abandonment. In it were recovered a polished stone axe, 3 whole pots -thickened rim plate and bowls-, bone tools -a needle, a spatula and a worked bovid phalanx-, and a deer antler. The absence of domestic accumulation and debris within the pit may support the ritual/votive hypothetical use of the pit.

Phase III is characterized by a set of structure made of small stone circles of $1.2 \mathrm{~m}$ diameter, with no material cultural remains.

\section{METHODS: FIELD WORK AND SAMPLING}

AMS-14C sample was collected from a deer antler appeared in a pit associated to the last used living floor (SU 9/10) and is expected to date the initial moment of the last habitation of the site, prior to its abandonment, thus it is expected to be in good agreement with LM2 OSL date.

Samples for luminescence dating were collected from square H22 South profile. Two samples were taken for full dating from the two main phases where human habitation occurred: (1) LM1 from the open-firing structure (SU 18b) to fully date the associated living floor (SU 16); and 
(2) LM2 from the last living floor (SU 9/10) associated to Phase II, prior to the abandonment of the site. These were collected by driving stainless steel tubes into the section, which were subsequently sealed to retain moisture. These sampling holes were enlarged and gamma spectrometry measurements made in situ. In addition to the tubes collected for full dating, seven small samples were taken for luminescence profiling by driving a tube into the section and extruding each sample into an opaque container (Fig. 3). These were selected to provide stratigraphic context to the full dating results by permitting evaluation of changes in depositional process and luminescence behaviour through the stratigraphy.

\subsection{Luminescence and Dosimetric measurements}

The luminescence signal builds up in minerals as electrons liberated by the impact of ionizing radiation are trapped in defects in the crystal lattice (Burbidge 2012). These are released by exposure to light, or sufficient heat, and begin to accumulate again once a mineral grain is buried: Luminescence Age (a) = Absorbed Dose (Gy) / Dose Rate (Gy/a).

To measure the dose absorbed by the crystal since the event of interest (Absorbed Dose), it is heated (Thermally Stimulated Luminescence, TSL) or exposed to light (Optically-or Infrared-Stimulated Luminescence, OSL or IRSL) to stimulate the accumulated signal. This signal is calibrated relative to that produced by known doses administered in the laboratory. Luminescence measurements were made using Risø DA15 and DA-20 TSL/OSL readers equipped with ${ }^{90} \mathrm{Sr} /{ }^{90} \mathrm{Y} \beta$ sources in calibrated geometries, and a photomultipliers with U340 filters for detection of blue-UV emissions.

For dating determinations the Absorbed Dose was measured using optically stimulated luminescence, with the single aliquot regenerative dose protocol (SAR OSL; Murray and Wintle 2000) of 90-160 $\mu \mathrm{m}$ quartz grains. Their preparation included density separation at 2.62 and 2.7 $\mathrm{g} / \mathrm{cm}^{3}$ and 2 cycles of $40 \%$ HF treatment followed by re-sieving. $24 \sim 5 \mathrm{~mm}$ diameter aliquots were measured per sample. Natural signals were calibrated relative to a set of laboratory doses designed to bracket them, for preheat temperatures between 180 and $280{ }^{\circ} \mathrm{C}$. Initial data reduction was carried out using Analyst software. Results from individual subsamples were rejected if apparent poor behaviour within the sequence had a significant effect on the measured Absorbed Dose. A weighted maximum likelihood estimate of the Absorbed Dose of the sample was calculated based on the assumption of a single normal population in the remaining data. For luminescence profiling, a basic series of preparatory treatments was used (Burbidge 2007), to separate fine coarse (90-250 $\mu \mathrm{m})$ polymineral and $40 \% \mathrm{HF}$ etched fractions, the latter expected to be dominated by quartz. Two aliquots from each fraction were subjected to simple regenerative Absorbed Dose determinations using IRSL and post IR OSL with test-dose monitoring, and post IR \& OSL TSL. This rapidly produced matrices of luminescence sensitivity and Absorbed Dose values through the section, including paired reproducibility assessment (Fig. 4).

Average dose rate, since the OSL signal was last reset, was based on $\mathrm{NaI}$ gamma spectrometry in the field, neutron activation analysis and water content measurements of samples and associated sediments in the laboratory. A 1 hour gamma spectrometry measurement was made using a Target Nanospec system with ' 2 × 2' probe, originally calibrated for efficiency in natural background radiation fields relative to the 'oxford blocks'. The spectra were stripped to evaluate effective concentrations of $\mathrm{K}, \mathrm{Th}$ and $\mathrm{U}$ in the environments of the samples. Neutron activation analysis was conducted following irradiation in the Portuguese Research Reactor (Dias and Prudêncio 2007).

Alpha, beta and gamma dose rates were calculated from the concentrations, taking into account the measured as-sampled and estimated time averaged-burial water content of each sample. Time averaged burial water content was estimated as the average of measured values as-sampled, and those following saturation and free drainage for 8 days. INAA results were corrected for the time averaged value; $\mathrm{NaI}$ results were corrected for the difference between this and the as-sampled water content. These dose rates were combined based on approximations of the geometries represented by each measurement for each type of radiation, relative to the mineral grains used for Absorbed Dose estimation. The cosmic dose rate was calculated based on sample 


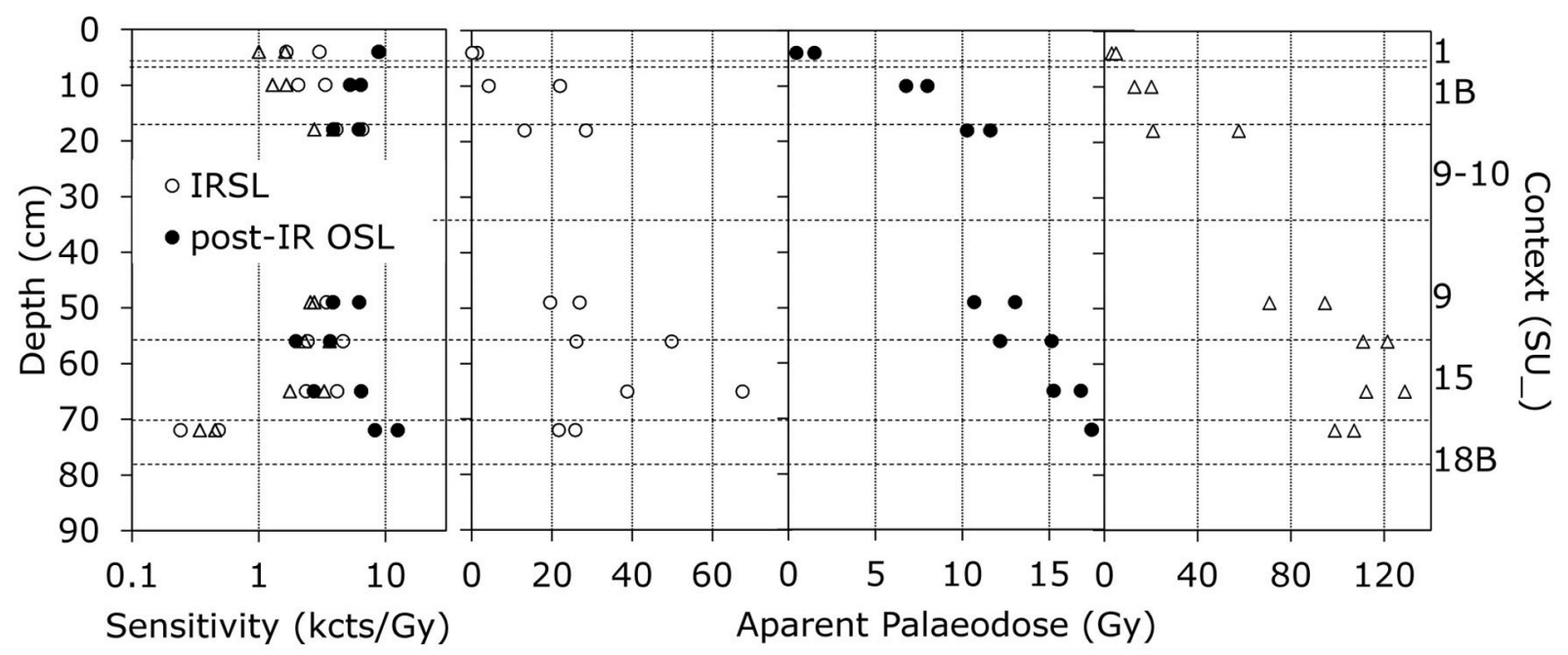

Fig. 4. Las Mesas square H22 stratigraphy. South profile (after Hurtado et al. 2008).

location and as-sampled burial depth, assuming this to be representative due to phases of accumulation and erosion evident in the upper section. It was calculated following Prescott and Stephan (1982), and using a fit to the data of Prescott and Hutton (1988) to include the soft component.

\subsection{AMS-Radiocarbon}

The measurements were made at the CNA (Centro Nacional de Aceleradores) AMS facility of the University of Sevilla using a 1 MV AMS. Chemical preparation of the samples followed standard procedures (Santos Arevalo 2009). Soxhlet extraction was applied using hexane, acetone and ethanol before treating the samples with the Acid-Alkali-Acid cleaning procedure. For the AAA procedure $\mathrm{HCl} 0.5 \mathrm{M}$ and $\mathrm{NaOH} 0.1 \mathrm{M}$ were used, and time was carefully controlled to avoid severe losses by dissolution.

Between 7-10 mg of clean and dry antler were combusted at $950{ }^{\circ} \mathrm{C}$ for $3 \mathrm{~h}$ in a vacuum-sealed quartz tube with $\mathrm{CuO}$ and $\mathrm{Ag}$ powder. Quartz tubes had been previously baked at $950{ }^{\circ} \mathrm{C}$ to eliminate possible organic matter. Produced $\mathrm{CO}_{2}$ was then reduced to graphite by adding excess $\mathrm{H}_{2}$ and using cobalt as catalyst. The resultant mixture of graphite and cobalt was pressed into aluminium cathodes and kept on vacuum until measurement (Santos Arevalo 2009).

\section{RESULTS}

The site was poor in organic materials suitable for AMS-radiocarbon dating. Only a deer antler was collected from the pit (SU 19). The results are presented in table 2. AMS-14C dates are reported in conventional radiocarbon years before present in accordance with (Stuiver 1977). The results have been calibrated using Calib 6.0 (2010) based on (Stuiver 1993) with intcal'09 (Reimer 2009). Calibrated age is presented in calendar years cal. BC, and in table 2 also as BP.

\begin{tabular}{|c|c|c|c|c|c|c|}
\hline Lab Code & $\begin{array}{l}\text { Context } \\
\text { (Depth) }\end{array}$ & Type & $\begin{array}{c}{ }^{14} \mathrm{C} \text { Age } 1 \delta \\
\text { years BP }\end{array}$ & Cal. Age BCE & Cal. age BP & $\delta^{13} \mathrm{C} \%$ \\
\hline CNA 763 & $\begin{array}{l}\text { SU } 19 \\
(0.9 \mathrm{~m})\end{array}$ & Deer antler & $4255 \pm 45$ & $\begin{array}{l}\mathbf{2 9 1 6 - 2 8 6 7}(\mathbf{0 , 7 8 \%}) \\
2804-2776(0,20 \%) \\
2768-2764(0,02 \%)\end{array}$ & $\begin{array}{l}\mathbf{4 8 1 6}-4865(\mathbf{0 , 7 8 \%} \%) \\
4725-4753(0,20 \%) \\
4713-4717(0,02 \%)\end{array}$ & $-21.19 \pm 0.43$ \\
\hline
\end{tabular}

Tab. 2. Radiocarbon date from Las Mesas (CNA 763, deer antler, SU 19). 


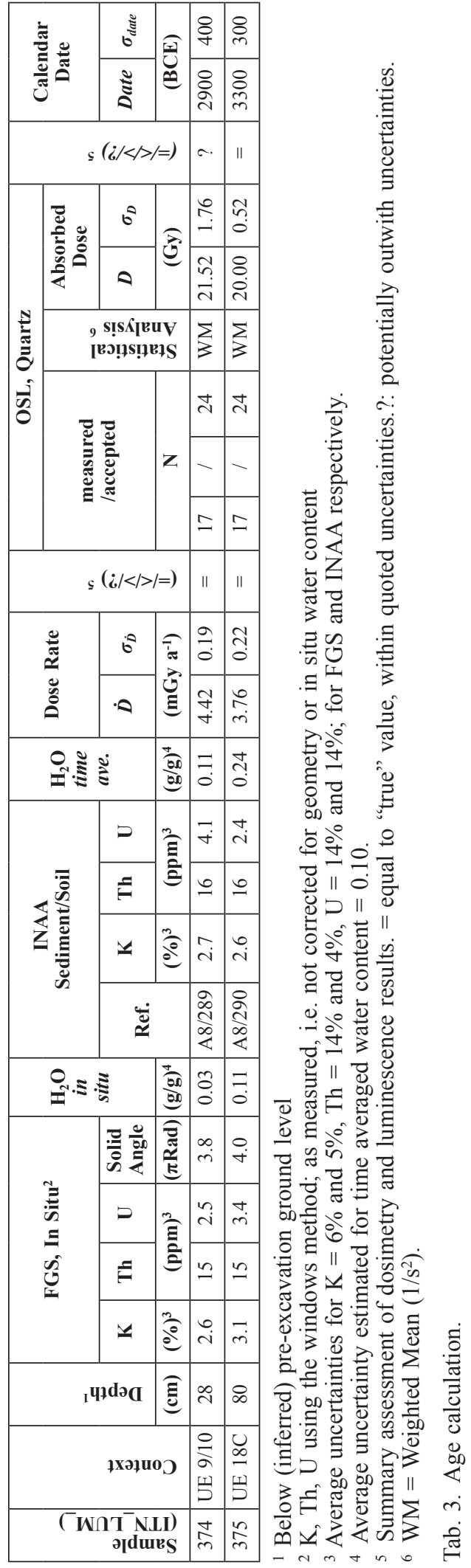

The luminescence dates are presented in calendar years (BC). Although the natural Optically stimulated luminescence signal of the samples is low in the modern topsoil at Las Mesas, above layer 1 absorbed dose increased rapidly with depth to a plateau in SU 9/10 \& 9, followed by higher values in SU 15. Below SU 15 IRSL results indicated a return to the levels observed in SU 9, which would imply the presence of residual signals in SU 15. This issue may indicate an occupational gap between both phases. OSL profiling results were lower because of signal saturation and calibration relative to a single dose, but exhibited a similar qualitative pattern with depth, except for a continued increase in Absorbed Dose into SU 18.

Profiling shows high luminescence sensitivities in all sedimentary layers at Las Mesas, but SU 18 (open-fire structure) displayed distinctly lower IRSL and TSL sensitivities than the remainder (Fig. 4), and the difference was even more evident following HF treatment. This indicated a greater signal contribution from quartz, and that the remaining IR sensitive minerals were relatively easy to remove. The profiling results were borne out in the full dating samples, where a significant IR stimulable component was observed in all aliquots of the material prepared from sample LM1 and the OSL results were scattered (ITN LUM 374), whereas the same treatment resulted in "clean" OSL signals and reproducible results from sample LM2 (ITN LUM 375). Optical microscopy confirmed the presence of inclusions in the grains of samples LM1, and that they were highly pitted following HF treatment. The sediments appeared to be relatively similar silty sandy clays, but with different levels of organic/ashy material (LM2>LM1) and differing quantities and sizes of clast (LM1>LM2): LM2 was found to retain substantially more water than LM1. Despite these differences, values for the Absorbed Doses, dose rates, and hence date estimates for these samples were always within $2 \sigma$ of each other, and both yielded values within $1 \sigma$ of $3000 \mathrm{BC}$ (Tab. 3).

\section{DISCUSSION AND CONCLUSIONS}

The present results indicate that the archaeological formation of Las Mesas site can be relia- 
bly attributed to the Late Neolithic-Early Copper Age period. Previous assessments based on material culture suggested a general chronological span from Middle (ca. 2900-2600 BC) through Late Copper Age (ca. 2600-1800 BC). Here we refine the chronology and show unambiguous attribution of the site to the Late Neolithic-Early Copper Age period-Araya phase.

Luminescence analyses indicate that the upper archaeological layer (SU 1b) would probably date to the Late Bronze Age (ca. $1000 \mathrm{BC})$, but that the sediments in the remainder of this profile accumulated or were emplaced by people in the late Neolithic-Early Copper Age: the site was most probably inhabited between 3300 and 2900 BC. An occupational gap between both Late Neolithic-Cooper Age phases (I \& II), and between Late Neolithic-Cooper Age phases and Late Bronze Age phase (II \& III), would indicate that the site was abandoned and reoccupied twice: once in the Copper Age and other time in the Late Bronze Age. The occupational gap recorded by luminescence between phase I \& II may be related to an episode of violence observed in the walls where reconstruction and consolidation duties were undertaken marking the edge between both phases (1).

In summary, Las Mesas site appears to have been first occupied during Late Neolithic-Early Copper Age and abandoned at the beginning of the Middle Copper Age period, then reoccupied during Late Bronze Age. This indicates that the site was contemporary with the first farming colonization of Tierra de Barros County, and probably with Araya and El Lobo sites. During this period the site was abandoned once as observed by a chronostratigraphic discontinuity in the luminescence profiling measurements.

The period of occupation of this site appears remarkably short compared to the long lasting use of thickened rim plates, which accounts for more than a millennium. Thus this pottery type must be used carefully in the modelling of cultural evolution processes and social dynamics.

(1) The absence of organic material and the economic and administrative constraints made impossible to date the destruction and reconstruction episodes recorded on these walls. Therefore, these episodes on the biography of the walls are related to the chronological sequence recorded at the centre of the site.
During abandonment periods, the population inhabiting Las Mesas may have moved either to El Monte, just opposite Las Mesas at the other bank of the Guadajira River or suffered an aggregation process elsewhere, as is proposed for Perdigões (Valera 2006). From our point of view Copper Age population density may be overestimated if chronologies are based on surveys and pottery seriation, because thickened rim plates are in use for more than a millennia. Thus, systematic dating of known sites must be made to solve perennial problems in Iberian Copper Age archaeological research, such as the contemporary vs. diachronic natures of the Copper Age sites, social dynamics as farming colonization, aggregation processes, sites hierarchy or social, political and/or economic dominance, ...

\section{ACKNOWLEDGEMENTS}

The authors acknowledge the Ministerio de Economía y Competitividad (HAR2012-34620) and the Fundação para a Ciência e a Tecnologia for financial support; and the Ministerio de Ciencia e Innovación for a postdoctoral Grant under the program Juan de la Cierva (JCI-2011-10491).

\section{BIBLIOGRAPHY}

Aitken, M. J. 1985: Thermoluminescence Dating, U.S. ed. Academic Press. London.

Burbidge, C. I. 2012: "Facets of Luminescence for Dating". Spectroscopy Letters 45:118-126.

Burbidge, C. I.; Sanderson, D. C. W.; Housley, R. A. and Allsworth Jones, P. 2007: "Survey of Palaeolithic sites by luminescence profiling, a case study from Eastern Europe". Quaternary Geochronology 2: 296-302.

Dias, M. I. y Prudêncio, M. I. 2007: "Neutron Activation Analysis of Archaeological Materials: An Overview of the Itn Naa Laboratory, Portugal". Archaeometry 49: 383-393.

Enríquez Navascués, J. J. 1989: Los poblados calcolíticos de la cuenca del Guadiana. Aproximación al estudio de los comprendidos entre las vegas altas y bajas del Guadiana (la comarca de Mérida). Colecciones tesis doctorales. Universidad Complutense de Madrid. Madrid.

Garcia Sanjuán, L. and Hurtado, V. 1997: "Los inicios de la jerarquización social en el Suroeste de la Península Ibérica (c.2500-1700 ane). Problemas conceptuales empíricos". Saguntum 30: 135-152. 
Hurtado, V. 1981: "Las figuras humanas del yacimiento de La Pijotilla (Badajoz)". Madrider Mitteilungen 22: 78-89.

Hurtado, V. 1991: "Informe de las excavaciones de urgencia en 'La Pijotilla'. campaña de 1990”. Extremadura Arqueológica II: 45-67.

Hurtado, V. 1995: “Interpretación sobre la dinámica cultural en la Cuenca Media del Guadiana (IVIII milenios ANE)". Extremadura Arqueológica V: 53-80.

Hurtado, V. 1999: "Los inicios de la complejización social y el campaniforme en Extremadura". SPAL 8: 47-83.

Hurtado, V. 2004: "El asentamiento fortificado de San Blas (Cheles, Badajoz). III milenio AC". Trabajos de Prehistoria 61(1): 141-155.

Hurtado, V. and Enríquez Navascués, J. J. 1991: “Excavaciones En Palacio Quemado (Alange, Badajoz), Informe Preliminar". Extremadura Arqueológica II: 46-68.

Hurtado, V.; García Rivero, D. and Odriozola, C. P. 2008: Las Mesas. Memoria de excavaciones arqueológicas. Alamut S. L. Estudios de Arqueología y Patrimonio. Badajoz.

Hurtado, V. and Mondejar, P. 2008: "Prospecciones en Tierra de Barros (Badajoz). Los asentamientos del III milenio A.N.E.". En R. Cruz-Auñón Briones and E. Ferrer Albelda (eds.): Estudios de Prehistoria y arqueología en homenaje a Pilar Acosta Martínez. Universidad de Sevilla. Sevilla: 187-206.

Hurtado, V.; Mondejar, P. and Pecero, J. C. 2000: "Excavaciones en La Tumba 3 de La Pijotilla". Extremadura Arqueológica VIII: 249-266.

Murray, A. S. and Wintle, A. G. 2000: "Luminescence Dating of Quartz Using an Improved SingleAliquot Regenerative-Dose Protocol". Radiation Measurements 32: 57-73.
Odriozola, C. P.; Hurtado, V.; Dias, M. I. and Prudêncio, M. I. 2008: "Datación por técnicas luminiscentes de la Tumba 3 y el conjunto campaniforme de La Pijotilla (Badajoz, España)". VII Congreso Ibérico de Arqueometría (Madrid 2007): 211-225. Madrid.

Prescott, J. R. and Hutton, J. T. 1988: "Cosmic Ray and Gamma Ray Dosimetry for Tl and Esr". Nuclear Tracks and Radiation Measurements 14: 223-227.

Prescott, J. R. and Stephan, L. G. 1982: "The Contribution of Cosmic Radiation to the Environmental Dose for Thermoluminescent Dating-Latitude, Altitude and Depth Dependences". PACT 6: 17-25.

Reimer, P. J.; Baillie, M. G. L.; Bard, E.; Bayliss, A.; Beck, J. W.; Blackwell, P. G.; Bronk Ramsey, C.; Buck, C. E.; Burr, G. S.; Edwards, R. L.; Friedrich, M.; Grootes, P. M.; Guilderson, T. P.; Hajdas, I.; Heaton, T. J.; Hogg, A. G.; Hughen, K. A.; Kaiser, K. F.; Kromer, B.; McCormac, F. G.; Manning, S. W.; Reimer, R. W.; Richards, D. A.; Southon, J. R.; Talamo, S.; Turney, C. S. M.; van der Plicht, J. and Weyhenmeyer, C. E. 2009: "IntCal09 and Marine09 Radiocarbon Age Calibration Curves, 0-50,000 Years cal BP”. Radiocarbon 51, 4: 1111-1150.

Santos Arevalo, F. J.; Gómez Martínez, I. and García León, M. 2009: "Radiocarbon Measurement Programme at the Centro Nacional de Aceleradores (CNA)". Radiocarbon 51, 2: 883-889.

Stuiver, M. and Polach, H. A. 1977: "Discussion: reporting 14C data". Radiocarbon 19, 3: 255-363.

Stuiver, M. and Reimer, P. J. 1993: "Extended 14C data base and revised CALIB 3.0 14C Age calibration program Radiocarbon". Radiocarbon 35, 1: 215-230.

Valera, A. C. 2006: “A margem esquerda do Guadiana (regiao de Mourao), dos finais do $4 .^{\circ}$ Aos inícios do 2. Milénio AC". ERA-Arqueologia 7: 136-210. 